\title{
CERTAIN RESULTS OF MEASUREMENTS OF CHARACTERISTICS OF STRATOSPHERIC AEROSOL LAYER AND TOTAL OZONE CONTENT AT SIBERIAN LIDAR STATION IN TOMSK Aleksey Nevzorov", Oleg Bazhenov, Vladimir Burlakov and Sergey Dolgii
}

\author{
V.E. Zuev Institute of Atmospheric Optics, Siberian Branch, Russian Academy of Sciences, Tomsk
} 634021, Russia, "e-mail: nevzorov@iao.ru

\begin{abstract}
We consider the results of long-term remote optical monitoring, obtained at the Siberian Lidar Station of Institute of Atmospheric Optics, Siberian Branch, Russian Academy of Sciences in Tomsk $\left(56.5^{\circ} \mathrm{N}, 85.0^{\circ} \mathrm{E}\right)$. The scattering characteristics of stratospheric aerosol layer, obtained according to data of lidar measurements since 1986, are presented. We analyze the trends of changes in the total ozone (TO) content over Tomsk for the period 1996-2013 according to data of spectrophotometric measurements with employment of Total Ozone Mapping Spectrometer (TOMS) data for the period 19791994. We determined the periods of elevated content of stratospheric aerosol over Tomsk after a series of explosive eruptions of volcanoes of Pacific Ring of Fire and Iceland in 2006-2011. Since the second half of 1990 s, we record an increasing TO trend, equaling $0.65 \mathrm{DU} / \mathrm{yr}$ for the period 1996-2013.
\end{abstract}

\section{INTRODUCTION}

The most important constituents and parameters of the atmosphere, which determine its radiationtemperature regime and chemical balance, are stratospheric aerosol, ozone, gas components of ozone cycles, and temperature. The scattering and absorbing properties of the stratospheric aerosol and gas constituents should be taken into consideration in radiation codes of the models of atmospheric general circulation and climate. Since early 2000 s, there are signs of stabilization and even growth of the total ozone (TO), at separate regions [1]. The reasons for the TO stabilization signs are still debatable: whether these are (1) due to the implementation of Montreal protocol and subsequent amendments, which came into force in 1989 and stated that anthropogenic emissions of ozone-depleting gases should be reduced, or they are (2) because the stratosphere from 1997 to 2006 was under the conditions of long-term volcanically quiescent period with minimal content of stratospheric aerosol (SA), which is a strong ozone-depleting factor. Therefore, the integrated remote monitoring of the state of stratospheric aerosol and ozone layers with the purpose of studying the physical mechanisms and tendencies of their changes is still urgent.

Studies of the physical mechanisms of atmospheric changes rely upon obtaining and subsequent statistical and correlation analysis of time series of long-term regular measurements. This analysis makes it possible to develop empirical models of atmospheric parameters; determine seasonal, quasibiennial, and other periodic cycles of variations; study the mechanisms that determine the dynamics and interrelations of measured parameters; reveal short-term disturbances of the atmosphere and gradually accumulated changes under the impact of natural and anthropogenic factors; and, ultimately, determine and predict the trends of atmospheric changes, together with providing estimates of degree of their effect on possible climate changes. This approach to studying the atmospheric changes on the basis of regular integrated remote optical monitoring is one of the priority directions in the present-day word practice of atmospheric studies.

\section{MEASUREMENT INSTRUMENTATION}

The atmospheric observatory, i.e., the Siberian Lidar Station (SLS), had been created in V. E. Zuev Institute of Atmospheric Optics, Siberian Branch, Russian Academy of Sciences; it operates in Tomsk $\left(56.5^{\circ} \mathrm{N} ; 85.0^{\circ} \mathrm{E}\right)$ and comprises the set of modern means of remote laser and passive sensing for studying the aerosol and cloud fields, temperature and humidity, ozone, and gas components of ozone cycles. Aside from its broad coverage of monitored atmospheric parameters, the observatory is unique in that it permits atmospheric monitoring simultaneously in the entire significant altitude range of $0-70 \mathrm{~km}$. The 
observatory includes the following instrumental complexes.

1. Multichannel stationary lidar complex on the basis of 0.3-, 0.5-, and 2.2-m diameter receiver mirrors for monitoring the optical and meteorological parameters and gaseous composition of the atmosphere in the altitude range of $5-70 \mathrm{~km}$, thus covering the upper troposphere, stratosphere, and mesosphere.

2. Spectrophotometer complex for daily automatic measurements of total ozone content (at daytime) and twilight (morning - evening) measurements of the vertical distribution $(0-50 \mathrm{~km})$ and total content of $\mathrm{NO}_{2}$.

\section{RESULTS OF MONITORING THE STRATOSPHERIC AEROSOL LAYER}

Lidar measurements of SA scattering characteristics have been conducted at SLS since 1986. Sensing is performed at the wavelength of $532 \mathrm{~nm}$ of Nd:YAG laser. Optical lidar signals are received using $0.3-\mathrm{m}$ diameter mirror. Photoelectron recording of lidar signals is performed in photocurrent pulse counting mode.

The numerous studies of ozonosphere state after powerful volcanic eruptions such as El Chichon (1982), Pinatubo (1991), and others, performed abroad and at Institute of Atmospheric Optics, Siberian Branch, Russian Academy of Sciences, show the effect of elevated SA content on destruction of ozone layer, when TO depletion is observed for a few years after eruption [2-4]. The radiation-temperature and other stratospheric changes make it possible to study and evaluate field lidar observations in the periods of explosive volcanic eruptions, when sulfur-containing products are injected directly to the stratosphere, where they form additional sulfuric acid aerosol.

However, even a series of weak explosive volcanic eruptions can lead to marked radiationtemperature changes because, by scattering the solar radiation, the stratospheric aerosol layer (SAL) with increased content of volcanic aerosol reduces the solar radiative influx to the Earth's surface. After the long-term volcanically quiescent period 1997-2005 there had been a series of weak eruptions of volcanoes of Pacific Ring of Fire and Iceland, which increased the SA content [5-7]. These volcanoes could have a cooling effect on global climate $[8,9]$.

We identified the periods with elevated content of stratospheric aerosol over Tomsk on the basis of lidar measurements of integrated aerosol backscattering coefficient $\mathrm{B}_{\pi}{ }^{\mathrm{a}}$ (Table 1). In 20122014, we recorded background SA content over Tomsk.

Figure 1 shows the time behavior of $\mathrm{B}_{\pi}{ }^{\mathrm{a}}$, determined according to data of sensing at the wavelength of $532 \mathrm{~nm}$. In this figure, every point represents data, averaged over 10 days of measurements.

Table 1. Chronology of volcanic eruptions, traces of which were recorded in the stratosphere over Tomsk in 2006-2011.

\begin{tabular}{|c|c|c|c|}
\hline Volcano & $\begin{array}{c}\text { Latitude, } \\
\text { Longitud } \\
\text { e, deg. }\end{array}$ & Date & $\begin{array}{l}\text { Period of aerosol } \\
\text { disturbance of the } \\
\text { stratosphere }\end{array}$ \\
\hline $\begin{array}{l}\text { Rabaul, } \\
\text { Papua New } \\
\text { Guinea }\end{array}$ & $\begin{array}{c}4.3^{\circ} \mathrm{S} \\
152.2^{\circ} \mathrm{E} .\end{array}$ & $\begin{array}{l}6 \text { Oct } \\
2006\end{array}$ & $\begin{array}{c}\text { late October } 2006 \\
- \text { winter of } \\
2006 / 07\end{array}$ \\
\hline $\begin{array}{l}\text { Okmok, } \\
\text { Auletian } \\
\text { Islands }\end{array}$ & $\begin{array}{l}53.4^{\circ} \mathrm{N} \\
168.1^{\circ} \mathrm{W}\end{array}$ & $\begin{array}{l}12 \mathrm{Jul} \\
2008\end{array}$ & \multirow{2}{*}{$\begin{array}{c}\text { late July - fall of } \\
2008\end{array}$} \\
\hline $\begin{array}{l}\text { Kasatochi, } \\
\text { Aleutian } \\
\text { Islands }\end{array}$ & $\begin{array}{l}52.2 \mathrm{~N} \\
175.5^{\circ} \mathrm{W}\end{array}$ & $\begin{array}{l}6-8 \\
\text { Aug } \\
2008\end{array}$ & \\
\hline $\begin{array}{l}\text { Redoubt, } \\
\text { Alaska }\end{array}$ & $\begin{array}{l}60.5^{\circ} \mathrm{N} \\
152.7^{\circ} \mathrm{W}\end{array}$ & $\begin{array}{l}18 \mathrm{Mar} \\
-4 \mathrm{Apr} \\
2009\end{array}$ & April - May 2009 \\
\hline $\begin{array}{l}\text { Sarychev } \\
\text { Peak, Kuril } \\
\text { Islands }\end{array}$ & $\begin{array}{l}48.1^{\circ} \mathrm{N} \\
153.2^{\circ} \mathrm{E}\end{array}$ & $\begin{array}{c}12-16 \\
\text { Jun } \\
2009\end{array}$ & $\begin{array}{c}\text { July }- \text { December } \\
2009\end{array}$ \\
\hline $\begin{array}{l}\text { Eyjafjallajo } \\
\text { kull, } \\
\text { Iceland }\end{array}$ & $\begin{array}{l}63.6^{\circ} \mathrm{N} \\
19.6^{\circ} \mathrm{W}\end{array}$ & $\begin{array}{l}14 \text { Apr } \\
2010\end{array}$ & $\begin{array}{l}\text { Minor disturbance } \\
\text { of the lower } \\
\text { stratosphere in late } \\
\text { April } 2010\end{array}$ \\
\hline $\begin{array}{l}\text { Grimsvötn, } \\
\text { Iceland }\end{array}$ & $\begin{array}{l}64.4^{\circ} \mathrm{N} \\
17.3^{\circ} \mathrm{W}\end{array}$ & $\begin{array}{l}21 \\
\text { May } \\
2011\end{array}$ & $\begin{array}{l}\text { Second half-year } \\
\text { of } 2011\end{array}$ \\
\hline
\end{tabular}

There are periodic bursts of increased aerosol content after every next volcanic eruption; growing trend of SA content over the volcanic activity period $2006-2011$ had been $3.43602 \cdot 10^{-}$ ${ }^{7} \pm 1.27198 \cdot 10^{-7} \mathrm{sr}^{-1}$ per year $(6.7 \pm 0.2 \%$ per year $)$. Arrows indicate explosive volcanic eruptions and, 
in particular, those presented in the table. The maximum integrated aerosol backscattering coefficients of the stratosphere reached (4-5) $10^{-4}$ $\mathrm{sr}^{-1}$ in periods of increased SA content versus the average values $\sim 1.5 \cdot 10^{-4} \mathrm{sr}^{-1}$ for the background period 1997-2006, which were no higher than $2.5 \cdot 10^{-4} \mathrm{sr}^{-1}$ even in winter periods of maximal aerosol content.

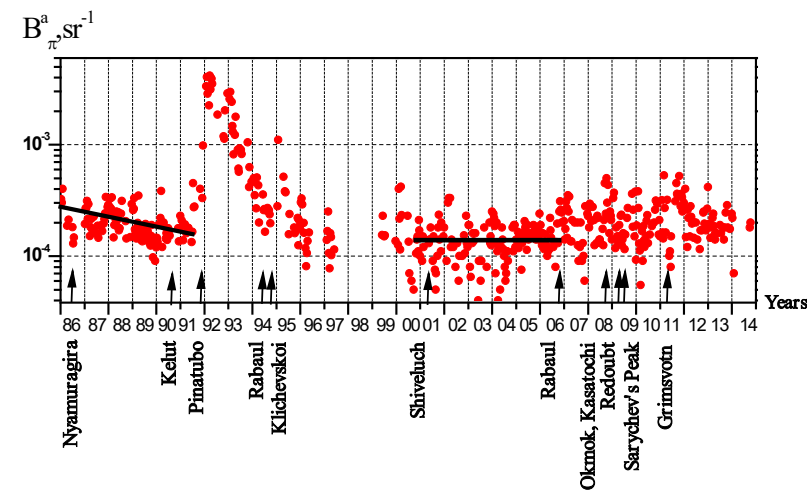

Figure 1. Dynamics of changes in the integrated aerosol backscattering coefficient at the wavelength $532 \mathrm{~nm}$ in the altitude range $15-30 \mathrm{~km}$ over Tomsk in 1986-2014. Straight lines show trend.

\section{MEASUREMENTS OF THE TOTAL OZONE CONTENT}

The spectrophotometric measurements of TO content have been conducted with M-124 ozonometer. Also, TOMS satellite data are employed to analyze the multiyear measurements.

The TO content, recorded by the present-day ground-based and satellite measurement facilities, had considerably depleted since early 1980s until mid-1990s. The decline until mid-1990s had conventionally and most often been attributed to the chemical ozone destruction due to the growing concentrations of ozone depleting substances (ODSs) in the stratosphere. Since the second half of 1990s to the present, the ozone layer stopped depleting almost everywhere or there are signs of increasing TO trend, most apparent at the Northern Hemisphere middle to high latitudes.

In April 2011, the ozone level had decreased by $30 \%$ as compared to multiyear average values (Fig. 2). In May 2011, the total ozone had largely returned to its seasonal behavior. However, its values remained lowered throughout 2011 and returned back only in the period of resumed wintertime ozone supply by the meridional transport from equatorial reservoir.

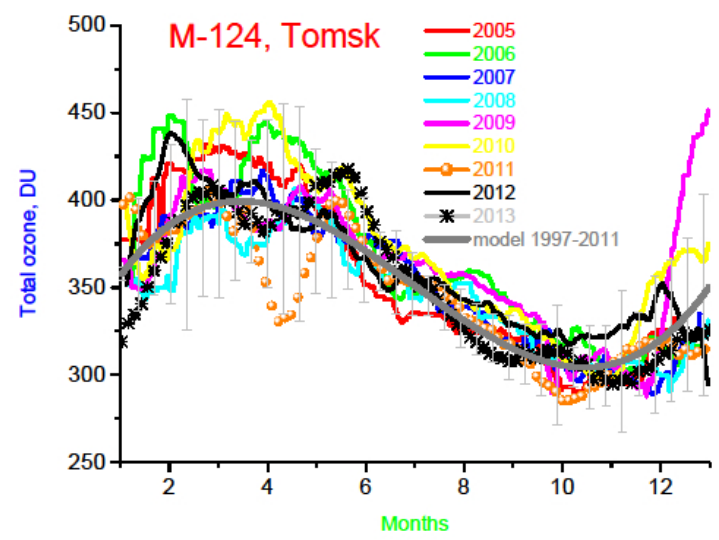

Figure 2. TO variations over Tomsk in 2005-2012 according to data of M-124 ozonometer measurements [10].

Figure 3 presents the trends of multiyear TO variations in different time intervals of period 1979-2013. Decreasing TO trend of $-2.35 \mathrm{DU} / \mathrm{yr}$ is evident for the period of $1979-1995$. Increasing TO trend, observed since 1996, was affected by the occurrence of ozone anomaly at Arctic latitudes during spring 2011. As a result of this phenomenon, the positive trend had decreased from 1.09 DU/yr for the period $1996-2010$ to $0.26 \mathrm{DU} / \mathrm{yr}$ for the period 1996-2011. In 20122013, the growing trend, like the ozone layer itself, started recovering and had been $0.44 \mathrm{DU} / \mathrm{yr}$ for the period 1996-2012 and 0.65 DU/yr for the period 1996-2013.

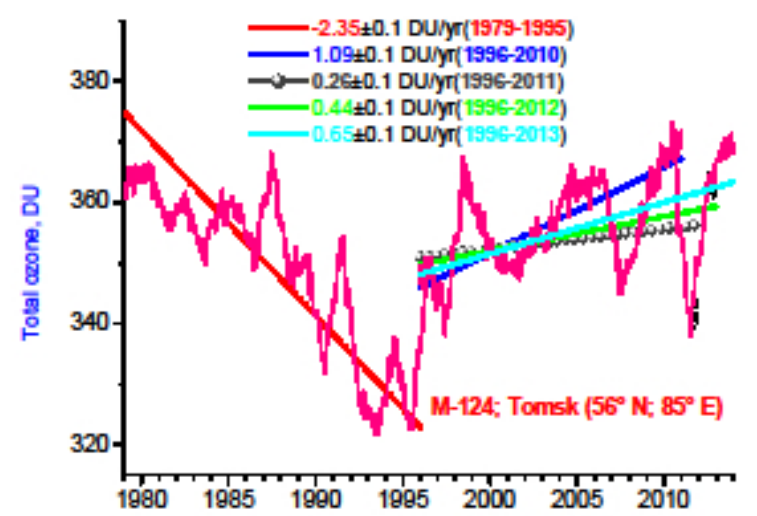

Figure 3. Total ozone time series for Tomsk $\left(56.48^{\circ} \mathrm{N} ; 85.05^{\circ} \mathrm{E}\right)$, plotted using TOMS satellite data (until 1993) and M-124 ozonometer data (since 1994). The time series was plotted using 365-point smoothing. The linear trends are plotted 
for the periods $1979-1995,1996-2010,1996-$ 2011, 1996 - 2012, and 1996 - 2013.

\section{CONCLUSIONS}

We determined the periods of elevated content of stratospheric aerosol over Tomsk after a series of explosive eruptions of volcanoes of Pacific Ring of Fire and Iceland in 2006-2011. The observed bursts of elevated aerosol content after every next volcanic eruption are periodic in character, and the increasing trend of stratospheric aerosol content over the volcanic activity period 20062011 had been $3.43602 \cdot 10^{-7} \pm 1.2719810^{-7} \mathrm{sr}^{-1}$ per year $(6.7 \pm 0.2 \%$ per year $)$. The maximal values of integrated aerosol backscattering coefficient of the stratosphere reached (4-5) $10^{-4} \mathrm{sr}^{-1}$ in periods of elevated SA content versus average values of $\sim 1.5 \cdot 10^{-4} \mathrm{sr}^{-1}$ for background period 1997-2006.

The destruction of ozone layer has stopped and there are signs for increasing TO trend since the second half of 1990s. This can be concluded from decreasing TO trend of $-2.35 \mathrm{DU} / \mathrm{yr}$ for period of 1979 - 1995 and increasing TO trend of $0.65 \mathrm{DU} / \mathrm{yr}$ for $1996-2013$.

\section{ACKNOWLEDGEMENT}

This work was supported in part by the Ministry of Education and Science of the Russian Federation under Agreement no. 14.604.21.0100, the Russian Science Foundation under Agreement no. 14-27-00022, and the President of the Russian Federation under grant NSh-4714.2014.5 ("Laser sensing of the atmosphere and ocean") for the support of leading scientific schools.

\section{REFERENCES}

[1] Weatherhead, E. C., and S. B. Andersen. 2006. "The search for signs of recovery of the ozone layer," Nature 441: 39-45, doi: 10.1038.

[2] Hofmann, D. J, and S. Solomon. 1989. "Ozone destruction through heterogeneous chemistry following the eruption of El Chichon," $J$. Geophys. Res. 94 (D4): 5029-5041.

[3] Ansmann, A., F. Wagner, U. Wandinger, I. Mattis, U. Görsdorf, H.-D. Dier, and J. Reichardt. 1996. "Pinatubo aerosol and stratospheric ozone reduction: Observations over central Europe." $J$. Geophys. Res. 101 (D13): 18,775-18,785.
[4] Zuev, V. V., O. E. Bazhenov, V. D. Burlakov, M. V. Grishaev, S. I. Dolgii, and A. V. Nevzorov. 2008. "On the effect of volcanic aerosol on variations of stratospheric ozone and $\mathrm{NO}_{2}$ according to measurements at the Siberian Lidar Station," Atm. Oceanic Opt. 21 (11): 825-831.

[5] Burlakov, V. D., S. I. Dolgii, and A. V. Nevzorov. 2011. "Lidar observations of the stratosphere aerosol disturbances over Tomsk $(56.5 \mathrm{~N} ; 85.0 \mathrm{E})$ in period of volcanic activity of 2006-2010." Opt. Atm. Okeana, 24 (12): 10311040.

[6] Vernier, J. -P., L. W. Thomason, J. -P. Pommereau, A. Bourassa, J. Pelon, A. Garnier, A. Hauchecorne, L. Blanot, C. Trepte, D. Degenstein, and F. Vargas. 2011. "Major influence of tropical volcanic eruptions on the stratospheric aerosol layer during the last decade," Geophys. Res. Lett. 38 (12): L12807, doi:10.1029/2011GL047563.

[7] Bourassa, A. E., A. Robock, W. J. Randel, T. Deshler, L. A. Rieger, N. D. Lloyd, E. J. Llewellyn, and D. A. Degenstein. 2012. "Large volcanic aerosol load in the stratosphere linked to Asian monsoon transport." Science 337: 78-81, doi:10.1126/science.1219371.

[8] Fyfe, J. C., K. Salzen, J. N. S. Cole, N. P. Gillett, and J. P. Vernier. 2013. "Surface response to stratospheric aerosol changes in a coupled atmosphere-ocean model," Geophys. Res. Lett. 40 (3): 584-588.

[9] Haywood, J. M., A. Jones, and G. S. Jones. 2014. "The impact of volcanic eruptions in the period 2000-2013 on global mean temperature trends evaluated in the HadGEM2-ES climate model," Atmospheric Science Letters 15: 92-96.

[10] Bazhenov, O. E., and A. V. Nevzorov. 2012. "Effect of ozone anomaly during spring of 2011 on long-term (1996-2011) trends of the total ozone content according to ground-based (Tomsk: $\left.56.48^{\circ} \mathrm{N}, \quad 85.05^{\circ} \mathrm{E}\right) \quad$ and satellite spectrophotometric measurements." In Proceedings of SPIE 8696, Eighteenth International Symposium on Atmospheric and Ocean Optics: Atmospheric Physics, 86960F (November 27, 2012); doi:10.1117/12.2007478. 